Diversity, Ethnicity, Migration and Work 
This page intentionally left blank 


\section{Diversity, Ethnicity, Migration and Work}

\section{International Perspectives}

Geraldine Healy

and

Franklin Oikelome 


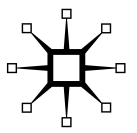

(c) Geraldine Healy and Franklin Oikelome 2011

Softcover reprint of the hardcover 1st edition 2011 978-0-230-25218-9

All rights reserved. No reproduction, copy or transmission of this publication may be made without written permission.

No portion of this publication may be reproduced, copied or transmitted save with written permission or in accordance with the provisions of the Copyright, Designs and Patents Act 1988, or under the terms of any licence permitting limited copying issued by the Copyright Licensing Agency, Saffron House, 6-10 Kirby Street, London EC1N 8TS.

Any person who does any unauthorized act in relation to this publication may be liable to criminal prosecution and civil claims for damages.

The authors have asserted their rights to be identified as the authors of this work in accordance with the Copyright, Designs and Patents Act 1988.

First published 2011 by

PALGRAVE MACMILLAN

Palgrave Macmillan in the UK is an imprint of Macmillan Publishers Limited, registered in England, company number 785998, of Houndmills, Basingstoke, Hampshire RG21 6XS.

Palgrave Macmillan in the US is a division of St Martin's Press LLC, 175 Fifth Avenue, New York, NY 10010.

Palgrave Macmillan is the global academic imprint of the above companies and has companies and representatives throughout the world.

Palgrave ${ }^{\circledR}$ and Macmillan ${ }^{\circledR}$ are registered trademarks in the United States, the United Kingdom, Europe and other countries.

ISBN 978-1-349-32176-6

ISBN 978-0-230-32147-2 (eBook)

DOI $10.1057 / 9780230321472$

This book is printed on paper suitable for recycling and made from fully managed and sustained forest sources. Logging, pulping and manufacturing processes are expected to conform to the environmental regulations of the country of origin.

A catalogue record for this book is available from the British Library.

Library of Congress Cataloging-in-Publication Data

Healy, Geraldine (Geraldine Mary)

Diversity, ethnicity, migration, and work: international

perspectives / Geraldine Healy, Franklin Oikelome.

p. $\mathrm{cm}$.

Includes index.

Summary: "Providing a comprehensive picture of diversity, ethnicity, and migration in the health sector this book analyses the key themes of career and career structures, social processes, segregation, racism and sexism at international, national and local levels" - Provided by publisher.

1. Health services administration. 2. Diversity in the workplace.

I. Oikelome, Franklin, 1969- II. Title.

RA971.H463 2011

$331.7^{\prime} 613621-\mathrm{dc} 23$

2011016925 


\section{Contents}

List of Tables viii

Acknowledgements $\quad$ xi

Glossary of Abbreviations $\quad$ xii

1 Working in the Health Services - Troubles, Issues, Migration and Ethnicity 1

2 Different Health Care Systems - Different Conditions? A Comparative Perspective 16 Introduction $\quad 16$

Setting the scene in the United Kingdom and United States - the debate on Obama's health care reform 16

Nigerian, UK and US health care through a comparative lens

The international health care workforce $\quad 25$

Conclusion 34

3 Diversity, Ethnicity, Migration and Work: UK and US Perspectives

Introduction

Diversity management - background 37

UK inequalities: historical and institutional responses $\quad 40$

Migration and the British legislative response $\quad 42$

Inequalities in health care work $\quad 47$

US inequalities: historical and institutional responses $\quad 54$

Working in health care in the United States 62

Conclusions $\quad 65$

4 Diversity, Ethnicity, Migration and Health in a

Developing Country - The Case of Nigeria 67

Introduction $\quad 67$

Ethnic diversity in Nigeria: issues, past and present 68

Managing diversity in Nigeria: policies and initiatives $\quad 73$

$\begin{array}{ll}\text { An assessment of the policies } & 76\end{array}$ 
The case of the health sector in Nigeria $\quad 79$

Administration $\quad 80$

$\begin{array}{lr}\text { Financing } & 81\end{array}$

Workforce and recruitment $\quad 81$

Migration of health workers $\quad 83$

Inequality and diversity issues $\quad 86$

$\begin{array}{lr}\text { Conclusions } & 89\end{array}$

5 International Medical Graduates - Working in a

Two-Tier System? $\quad 92$

Introduction $\quad 92$

International and UK Medical Graduates 94 Medical career grades $\quad 96$

Reward, workload, autonomy and morale 99

Discussion in comparative context 106

$\begin{array}{ll}\text { Conclusions } & 107\end{array}$

6 Gender and International Medical Graduates:

Historical, Contemporary and Intersectional

Perspectives $\quad 111$

Introduction $\quad 111$

Women's historical struggle into medicine 113

Women doctors: growth, segregation and international $\begin{array}{ll}\text { medical graduates } & 117\end{array}$

Gender, inequality, morale and career aspiration 122

Discussion and international perspectives 126

$\begin{array}{ll}\text { Conclusions } & 128\end{array}$

7 Front-line Hospital Workers and Inequalities: Social

Processes, Racism and Career Development 130

Introduction $\quad 130$

Researching Greenfield and Brownfield 132

Attitudes and experiences of working on the front-line in health care 136

Manifestations of racism $\quad 142$

Challenging unfair treatment 153

$\begin{array}{ll}\text { Conclusions } & 159\end{array}$

8 Challenging Inequality Issues: The Union Role 162

$\begin{array}{ll}\text { Introduction } & 162\end{array}$

Labour unions $\quad 163$

$\begin{array}{ll}\text { Union identity networks } & 164\end{array}$ 
Returning to Greenfield and Brownfield - perceptions and experiences of unions

Union membership in Greenfield and Brownfield 171

Experiencing trade unions in the workplace 176

How does the American experience compare? 180

At the front line 184

A journey to union involvement in the American health care sector

Conclusions

9 Identity Social Networks - Formal, Informal, Professional and Community

Introduction

Management-sponsored networks - back to Greenfield and Brownfield

Informal and external networks and social capital

Community organizations

Professional identity networks

Discussion

10 Managing Diversity in UK and US Health Care

Sector

Introduction

Revisiting the management of diversity

$$
\text { contexts }
$$

Diversity management initiatives

Equality and diversity projects in UK and US health care organizations

Discussion and conclusions

11 Reflections on Diversity, Ethnicity and Migration at Work at a Time of Change

Appendices

Notes

Bibliography

Index 


\section{List of Tables}

2.1 The Nigerian, UK and US health systems compared

2.2 Top 20 countries of medical education for US IMG physicians

2.3 US and IMG physician population overview

2.4 First-time, foreign-trained Registered Nurse (RN) candidates for US Licensure Examination, by top six exporting countries, 1997-2001

2.5 Top 20 countries of qualification for UK IMGs

2.6 Total number of nurses and midwives on UK register from 2004 to 2008

2.7 Initial admissions to the UK register: European economic area and overseas countries

2.8 Initial UK nursing admissions figures for 32 source overseas countries

3.1 UK non-medical staff by ethnic group

3.2 UK Hospital and Community Health Service (HCHS) medical and dental staff by grade and ethnicity

3.3 Race-based charges: 1997-2007

3.4 Key changes for African Americans since Civil Rights Act (1964)

4.1 Nigerian health worker population at national level

4.2 Nurses seeking employment outside Nigeria from 2004 to 2006

4.3 Nigerian doctors who requested for certificate of good standing and their destination countries for the years 2005-2007

4.4 Gender distribution by health occupation in Nigeria 2007

4.5 Number of health training schools by geographical distribution in Nigeria

4.6 Regional distribution of health workers: north and south of Nigeria

5.1 UK medical and dental staff 
5.2 UK medical staff by grade and country of qualification

5.3 Comparative experience of UKMGs and IMGs of reward, workload, autonomy and morale

6.1 UK doctors and IMGs by gender and grade

6.2 Medical and dental staff by speciality and gender (SAS only)

7.1 Characteristics of interviewees in Greenfield and Brownfield

8.1 Representation of women and BME members in UNISON structures

8.2 Union membership of Brownfield and Greenfield interviewees by sex

10.1 Cox and Blake (1991) and Dreachslin's (1999) diversity initiatives approaches

\section{Appendices}

A2.1 Top 20 US states IMGs practice (\% of state physician workforce)

A2.2 NHS HCHS and general practice workforce, 1998-2008 250

A2.3 Guide for doctors new to the UK (2008)

A2.3.1 How to get started: Immigration regulations for international doctors coming to the UK

A5.1 Definitions of variables used in regression models

A5.2 Regression coefficients of success, autonomy and workload on independent variables

A5.3 Proportion currently receiving discretionary points by qualification and gender

A5.4 Autonomy indicators by qualification and age groups

A5.5 Characteristics of survey respondents in full-time employment

A6.1 Physicians in the US by gender: 1970-2008

A6.2 Medical and dental staff NHS hospital and community health services

A6.3 Top Primary specialties: All IMG, male and female physicians

A6.4 Medical and dental staff by grade, gender and nature of contract

A6.5 Characteristics of survey respondents 
A6.6 Perception of inequality, morale and career aspiration 265 A6.7 Dependent variables by gender 265

A6.8 Dependent variables by gender and nature of contract 266 A6.9 Dependent variables by gender and place of qualification 268

A6.10 Dependent variables by place of qualification and nature of contract

A10.1 Diversity and race initiatives in NHS Trusts (UK) 271

A10.2 Diversity and race initiatives in US hospitals 286 


\section{Acknowledgements}

This book has its origins in a European Social Fund (ESF) project. We are grateful to the ESF for co-financing the original project. We would like to thank the various people who took part in the fieldwork, including officials from the Department of Health, NHS Employers, trade unions, trusts and NHS workers. We are particularly grateful to Professor Aneez Esmail and the BMA for enabling access to the data explored in Chapters 5 and 6. We also thank the hospitals and the staff who took part in the interview programme. The ESF project has since been developed to include a comparative focus and a broader sweep.

We are particularly grateful to those who took the time to read and comment on chapters in the book: Myrtle Bell (University of Texas) Chapter 3, Jonathan Harle (Association of Commonwealth Universities) - Chapter 4; Gill Kirton (Queen Mary, University of London) Chapter 10, Anne Munro (Napier University) - Chapter 7 and Ciara Silke - Chapter 2. Thanks too are due to Aideen Silke (Greenwich PCT) and Michael Brannan (Department of Health) for helpful discussions on key issues in the book and Terry Silke for proof reading the manuscript. We are grateful to Gloria Oikelome who undertook administrative work associated with the book. Thanks too are due to Virginia Thorp from Palgrave Macmillan for her early interest and support.

We would like to dedicate the book to the very young in our lives, to Patrick Silke Brannan and Sam Nayan Jackson, to Elizabeth Oluwakemi and David Oluwatosin Oikelome, with the hope that they will find a more just and fairer society as they reach adulthood. 


\section{Glossary of Abbreviations}

$\begin{array}{ll}\text { A \& E } & \text { Accident and Emergency } \\ \text { AAMC } & \text { Association of American Medical Colleges } \\ \text { AFL-CIO } & \begin{array}{l}\text { American Federation of Labour and Congress of } \\ \text { Industrial Organisations }\end{array} \\ \text { AFGE } & \begin{array}{l}\text { American Federation of Government Employees } \\ \text { American Federation of State, County and Municipal }\end{array} \\ \text { AFSME } & \begin{array}{l}\text { Employees } \\ \text { AmTerican Federation of Teachers }\end{array} \\ \text { AMA } & \text { American Medical Association } \\ \text { ANPA } & \text { Association of Nigerian Physicians in the Americas } \\ \text { AMMP } & \text { Association of Multicultural Members of Partners } \\ \text { BACH } & \text { Baltimore Alliance for Careers in Health } \\ \text { BCTGM } & \text { Bakery, Confectionary, Tobacco workers and Grain } \\ & \text { Millers Union } \\ \text { BMA } & \text { British Medical Association } \\ \text { BME } & \text { Black and Minority Ethnic } \\ \text { BAPIO } & \text { British Association of Physicians of Indian Origin } \\ \text { BWC } & \text { Black Workers' Conference } \\ \text { CERD } & \text { (United Nations) Committee on the Elimination of } \\ & \text { Racial Discrimination } \\ \text { CGFNS } & \text { Commission on Graduates of Foreign Nursing Schools } \\ \text { CPR } & \text { Conservatives for Patients' Rights } \\ \text { CRE } & \text { Commission for Racial Equality } \\ \text { DH } & \text { Department of Health } \\ \text { DWF } & \text { Diverse Workforce Facilitators } \\ \text { EEA } & \text { European Economic Area } \\ \text { EHRC } & \text { Equality and Human Rights Commission } \\ \text { EMAS } & \text { East Midlands Ambulance Service } \\ \text { EOC } & \text { Equal Opportunities Commission } \\ \text { ESL } & \text { English as a Second Language } \\ \text { EU } & \text { European Union } \\ \text { EWT } & \text { European Working Time } \\ \text { EWTD } & \text { European Working Time Directive } \\ \text { FCC } & \text { Federal Character Commission } \\ \text { FCT } & \text { Federal Capital Territory } \\ & \end{array}$




$\begin{array}{ll}\text { GDP } & \text { Gross Domestic Product } \\ \text { GED } & \text { Gender Equality Duty } \\ \text { GMC } & \text { General Medical Council } \\ \text { HCHS } & \text { Hospital and Community Health Service } \\ \text { HOPE } & \text { Having an Opportunity to Prepare for Employment } \\ \text { HPERU } & \text { Health Policy and Economic Research Unit (BMA) } \\ \text { HRM } & \text { Human Resource Management } \\ \text { HSMP } & \text { Highly Skilled Migrant Programme } \\ \text { IELTS } & \text { International English Language Testing System } \\ \text { IMG } & \text { International Medical Graduate } \\ \text { IQPC } & \text { International Quality and Productivity Centre } \\ \text { IBEW } & \text { International Brotherhood of Electrical Workers } \\ \text { IWL } & \text { Improving Working Lives } \\ \text { LGBT } & \text { Lesbian Gay Bisexual and Transgender } \\ \text { LINC } & \text { Ladders in Nursing Careers } \\ \text { LREAP } & \text { Leadership and Race Equality Action Plan } \\ \text { LGA } & \text { Local Government Area } \\ \text { LSA } & \text { Local Supervising Authority } \\ \text { MANSAG } & \text { Medical Association of Nigerian Specialists and General } \\ & \text { Practitioners in the British Isles } \\ \text { MBA } & \text { Masters of Business Administration } \\ \text { MPU } & \text { Medical Practitioner's Union } \\ \text { NANNM } & \text { National Association of Nigeria Nurses and Midwives } \\ \text { NCCG } & \text { Non-Consultant Career Grades } \\ \text { NCLEX } & \text { National Council Licensure Examination } \\ \text { NEA } & \text { National Education Association } \\ \text { NEC } & \text { National Executive Council } \\ \text { NHS } & \text { National Health Service } \\ \text { NMC } & \text { Nursing and Midwifery Council } \\ \text { NPF } & \text { Nigeria Police Force } \\ \text { NSCDC } & \text { Nigerian Security and Civil Defence Corps } \\ \text { NVQ } & \text { National Vocational Qualification } \\ \text { OECD } & \text { Organisation for Economic Cooperation and } \\ & \text { Development } \\ \text { OVQ } & \text { Overseas Qualified } \\ \text { PCT } & \text { Primary Care Trust } \\ \text { PLAB } & \text { Professional and Linguistic Assessment Board } \\ \text { PRN } & \text { Physicians for Responsible Negotiation } \\ \text { PSI } & \text { Policy Studies Institute } \\ \text { RRAA } & \text { Race Relations (Amendment) Act } \\ \text { RCN } & \text { Royal College of Nursing } \\ & \end{array}$




$\begin{array}{ll}\text { RED } & \text { Race Equality Duty } \\ \text { RN } & \text { Registered Nurse } \\ \text { SAS } & \text { Staff and Associate Specialist } \\ \text { SASG } & \text { Staff and Associate Specialist Group } \\ \text { SCOPME } & \text { Standing Committee on Postgraduate Medical and } \\ & \text { Dental Education } \\ \text { SCPMDE } & \text { Scottish Council for Postgraduate Medical and Dental } \\ & \text { Education } \\ \text { SDA } & \text { Sex Discrimination Act } \\ \text { SEIU } & \text { Service Employees International Union } \\ \text { SHO } & \text { Senior House Officer } \\ \text { SHA } & \text { Strategic Health Authority } \\ \text { SHB } & \text { Surrey Hampshire Borders } \\ \text { SOG } & \text { Self Organising Group } \\ \text { SYAS } & \text { South Yorkshire Ambulance Services } \\ \text { TELCO } & \text { The East London Communities Organisation } \\ \text { TUC } & \text { Trade Union Congress } \\ \text { UAW } & \text { United Automobile Workers } \\ \text { UCRIHC } & \text { Urban Central Region of Intermountain Health Care } \\ \text { UKMG } & \text { United Kingdom Medical Graduate } \\ \text { UKQ } & \text { United Kingdom Qualified } \\ \text { USMG } & \text { United States Medical Graduate } \\ \text { USW } & \text { United Steel Workers } \\ \text { WHO } & \text { World Health Organisation } \\ \text { WEHAG } & \text { Wirral Ethnic Health Advisory Group } \\ \text { WEHUG } & \text { Wirral Ethnic Health User Group } \\ \text { WILD } & \text { Women in Leadership Development } \\ \text { WYMAS } & \text { West Yorkshire Metropolitan Ambulance Service } \\ \end{array}$

